\title{
Implementation of Brizzi as an E-Money Payment Tools in Indonesia
}

\author{
Asri Elies Alamanda ${ }^{1}$, Tulus Sartono ${ }^{2}$ \\ 1 Postgraduate Study, Faculty of Law, Universitas Diponegoro, Indonesia \\ asrialamanda@gmail.com \\ ${ }^{2}$ Faculty of Law, Universitas Diponegoro, Indonesia \\ tulussartonoundip@gmail.com
}

\begin{abstract}
Introduction to The Problem: The rapid technological progress at this time has greatly influenced the development of the payment system in Indonesia. Innovations in electronic payment instruments have developed into more usable forms. Currently, like the other country, Indonesia is developing an electronic payment instrument known this day as e-money. Bank Rakyat Indonesia is one of the emoney issuer institutions, which issues Brizzi as an alternative non-cash payment instrument. The problem faced is that there are still many people who do not want to use e-money, especially Brizzi because they do not know the validity of using Brizzi e-money.
\end{abstract}

Purpose/Objective Study: This research aims to study the importance of Brizzi EMoney as a means of payment.

Design/Methodology/Approach: This research uses empirical juridical research methods to answer the validity of using Brizzi e-money as a payment method. This study uses primary data and secondary data. The primary data in this research are obtained from interviews at Bank Rakyat Indonesia, Merlung Branch. Other than that is secondary data collected through library research.

Findings: This research shows that the existence of e-money continues to experience significant development from 2009 until 2019. The legality of using Brizzi e-money and other e-money in Indonesia has been recognized as a legal payment instrument as regulated in the PBI on Electronic Money.

Paper Type: Research Article.

Keywords: E-Money; Brizzi; Payment

\section{Introduction}

Today's world is increasingly leading to the continued development of information and communication technology (Disemadi \& Roisah, 2019). The development of these technologies includes the development of the human payment system in carrying out daily life activities. Initially, the first payment system uses the barter system or exchanges a commodity (item) with other commodities directly (Firdaus, 2018). However, this barter system has limitations such as lack of efficiency and lack of standard agreement on the commodity value. Given these limitations and the development of an economy, a new payment system has emerged using money. 
Money is used as a medium of exchange that has a fixed value and has been accepted by the wider community. In Indonesia, money as a legal means of payment has been mentioned in Article 1, paragraph 2 of Act Number 7 of 2011 concerning Currency (Currency Act).

This rapid technological progress directly affects the development of payment systems in Indonesia. Initially, in its development, money as a legitimate payment instrument caused problems in its implementation, especially for large transactions (Lee \& Longe-Akindemowo, 1999). It has led to an electronic-based non-cash payment system (Anam, 2018). However, innovations in electronic payment instruments have developed into more usable forms. To overcome the massive transaction problem, which merely uses cash, Indonesia is developing a payment instrument known as electronic money or electronic money (e-money) (Firdaus, 2018). The most suitable e-money system is to save money on the much safer item that is known as a smart card and only use a rectangular plastic containing an electronic chip and provide much data to be read (Samsumar, 2016).

E-money defined as an electronic payment instrument in which the value of the money stored in certain electronic media (Widyastuti, Handayani, \& Wilarso, 2017). Users of e-money must deposit the money first with the publisher and store it in electronic media before using it. When used, the value of electronic money saved in electronic media will be reduced by the amount of the transaction, and after that, the users could reload the amount of their card whenever they want to. The use of emoney as an innovative and practical payment tool is simplifying the payment of economic activities that are mass, fast, and micro so that its development can help smooth payment transactions (Ramadhani, 2016). E-money currently circulating in the community include Brizzi issued by Bank Rakyat Indonesia (BRI), TapCash issued by Bank Negara Indonesia (BNI), Flazz issued by Bank Central Asia (BCA) and e-Money issued by Bank Mandiri. Some examples of e-money mentioned above basically have the same function, namely as a non-cash payment instrument, but only the features of each card that distinguish them, such as maximum balance, minimum top-up amount, maximum top-up per month and validity period. E-Money is an alternative non-cash payment instrument besides credit and debit cards. Emoney also offers its conveniences in its use (Ghozali \& Pambudi, 2018).

The existence of non-cash payment instruments such as e-money presented by Bank Indonesia is considered to help maximize purchasing power in the community, which will have an impact on increasing the country's economy (Sofyan, 2015). Although it is under development, the use of e-money will provide benefits and advantages compared to other payment instruments. Therefore, e-money has the potential to replace the role of credit cards because small-scale payments can be made quickly (Sudarsono, 2013). 


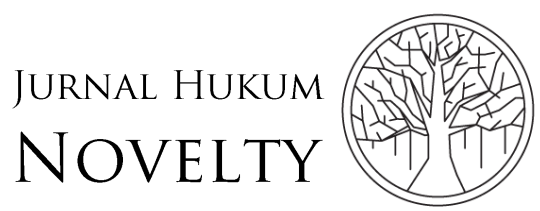

Volume 10, Issue 02, 2019, pp. 130-139

The implementation of e-money is part of digital financial service innovation, which also part of the National Non-Cash Movement (GNNT). It is intended to increase public awareness, business people, and also government institutions to use noncash payment facilities in conducting financial transactions, which is undoubtedly easy, safe, and efficient (Safitri \& Nainggolan, 2018).

Going forward, to create an efficient, safe, and reliable payment system while upholding consumer protection aspects, paying attention to expanding access and national interests, Bank Indonesia will increase the electronification of payment transactions and improve payment system infrastructure. In this framework, Bank Indonesia will arrange the centralization of utility bills payments and encourage the use of Government payment transactions electronically in a more effective and coordinated manner. So, the integration of the Electronic Bill Presentment System and Payment Service Integration between payment networks will also be developed to support this system (Safitri \& Nainggolan, 2018).

Along with the development of technology, e-money in Indonesia has developed so rapidly (Panurach, 1996). However, e-money as an alternative non-cash payment instrument also has a variety of potential risks that need to be addressed with caution from its users, such as the risk of electronic money being lost and can be used by other parties. In addition to the risk, the recently arised problem in the Indonesian community is the validity of using e-money in Indonesia. So to minimize the risk it is necessary and provides legal certainty regarding the use of e-money that needs arrangements regarding the implementation of e-money in the realization of a transparent and capable legal framework giving guarantees of protection to the community (Usman, 2017).

Considering research on e-money has been done previously, as carried out by Muhammad Ridwan Firdaus. In 2018 he studied the e-money from the Islamic Economy perspective. The result of his research is T-Cash as electronic money issued by PT. Telkomsel is a service offered to streamline the economic transaction process. Another similar study is the characteristic of e-money as a mean of payment. Rachmadi Usman concluded in his research that electronic money is cashless money that is stored on electronic media in the form of a server (hard drive) or chip card that functions as a means of payment (Usman, 2017). Choiril Anam, in 2018, he added other findings in his study that the use of electronic money will encourage consumption and public demand for goods and services, which in turn has the potential to promote activities in the real sector (Anam, 2019).

The focus of this research was the existence of the use of e-money in Indonesia and the legality of Brizzi use as a payment instrument issued by Bank Rakyat Indonesia. The formulated problems are: 1) how is the existence of e-money used in Indonesia? 2) what is Brizzi's legality as a legal payment instrument in Indonesia? 
P-ISSN: $1412-6834$

E-ISSN: 2550-0090

\section{Methodology}

In this research, the author uses empirical juridical research methods. Descriptive analysis is the method of the research specifications used by the authors because the specifications of this study describe the problem of the object studied by the author based on the factors that influence it..

The author uses primary data and secondary data in this article. Primary data is data obtained through respondents' interviews in the field. The primary data collected in this study are located in the Branch Office of BRI in Merlung-Jambi as a research sample. Data collected through observation techniques and side interview techniques. The interview technique used is the guided free interview technique, the results of which can be described by the writer in the discussion. Secondary data is data that obtained indirectly from the source of the research object. This data is in the form of legal material that has juridical binding power (primary legal document), legal material that provides further explanation of primary legal document such as books, articles and internet relating to the topic of this research (secondary legal document), and legal document that provides an explanation of the two legal documents above (tertiary legal document). The obtained data are then compiled for analysis and explanation to get the conclusions of the research conducted

The technique used in collecting primary data in this study is through interviews with respondents, while the methods used to collect secondary data are through library research or documentary studies, which are studies that examine various types of documents related to regulations, legislation, and other available materials. The last thing is to compile the data that has been obtaining so that it becomes legal writing that can answer the problems that have been formulated beforehand to help the author make a correct conclusion.

\section{Results and Discussion}

\section{The Existence of E-Money Use in Indonesia}

There are many choices for financial transactions. Moreover, the current technological advances that are so rapid make financial transactions easier with non-cash payments. Culture cashless society or the era of cashless payment systems. E-money is not something that sounds foreign to our ears. The emergence of emoney during society aims to reduce the growth rate of cash usage. Specifically for micropayments (Pranoto \& Salsabila, 2018).

Nowadays, e-money provides many programs that benefit the community. Various merchants collaborate with electronic money publishers to offer programs and encourage users to use e-money. The official generation can very quickly receive electronic money as a payment instrument because of exclusive promos and discounts given to users, ranging from discounts, cashback, free shipping, 0\% installments to free specific packages for e-money users (Kamnar, 2014). 


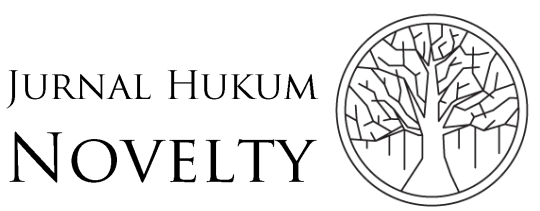

Volume 10, Issue 02, 2019, pp. 130-139

The implementation of e-money, which involves many parties, "requires Bank Indonesia (BI) to cooperate with several related institutions to promote non-cash transactions aimed at encouraging the public to reduce purchases using cash (Hanim, 2011). The use of non-cash transactions can reduce the circulation of money in Indonesia and promote the creation of a less-cash society. In this case, Bank Indonesia cooperates with other banks and other institutions to create a lesscash society, which aims to increase public awareness of the use of non-cash payment instruments to form the community, which uses non-cash payment instruments to carry out its economic activities (Tazkiyyaturrohmah, 2018).

Coordination and facilitation in the implementation and development of e-money are considered important by Bank Indonesia (BI) because the parties associated with the implementation of e-money are very diverse, such as e-money issuing institutions, merchants and other e-money support institutions. Here are 38 emoney publishers in Indonesia: 1) Bank Rakyat Indonesia, 2) Bank Central Asia, 3) Bank Negara Indonesia 1946 (Persero), 4) Bank Mandiri (Persero), 5) Bank Mega, 6) Cimb Niaga Bank, 7) Bank National Nobu, 8) Bank Permata, 9) QNB Bank Indonesia, 10) Sinarmas Bank, 11) DKI Jakarta BPD, 12) South Sumatra Babel BPD, 13) PT. Artajasa Payment Electronics, 14) PT. Dompet Anak Bangsa, 15) PT. Espay Debit Indonesia Koe, 16) PT. Finnet Indonesia, 17) PT. Indosat, 18) PT. Nusa Satu Inti Artha, 19) PT. Skye Sab Indonesia, 20) PT. Smartfren Telecom, 21) PT. Indonesian Telecommunications, 22) PT. Cellular Telecommunications, 23) PT. Witami Cash Mandiri, 24) PT. XL Axiata, 25) PT. Buana Media Technology, 26) PT. Bimasakti Multi Sinergi, 27) PT. Visionet International, 28) PT. Core of the World of Success, 29) PT. Veritra Sentosa International, 30) PT. Indonesia's Definite Solution, 31) PT. Ezeelink Indonesia, 32) PT. Bluepay Digital International, 33) PT. E2Pay Global Utama, 34) PT. Prosperous Ultima Chakra, 35) PT. Airpay Internasional Indonesia, 36). PT. Artha Gemilang Transaction, 37) PT. Fintek Karya Nusantara, and 38) PT. Max Interactives Technologies (Bank Indonesia (BI), 2019a).

The use of e-money by the Indonesian people was first in 2009 through a Bank Indonesia Regulation No.11/12/PBI/2009 concerning Electronic Money, better known as Electronic Money. The following are Bank Indonesia data from 2009 to 2019 with details:

1. In 2009 there were $3,016,272$ cards in circulation, and the number of transactions reached $17,436,631$

2. In 2010 there were $7,914,018$ cards in circulation, and the number of transactions reached $26,541,982$

3. In 2011 there were $14,299,726$ cards in circulation, and the number of transactions reached 41,060,149

4. In 2012 there were $21,869,946$ cards in circulation, and the number of transactions reached $100,623,916$

5. In 2013 there were $36,225,373$ cards in circulation, and the number of transactions reached $137,900,779$ 
6. In 2014 there were $35,738,233$ cards in circulation, and the number of transactions reached $203,369,990$

7. In 2015 there was $34,314,795$ cards in circulation, and the number of transactions reached $535,579,528$

8. In 2016 there were $51,204,580$ cards in circulation, and the number of transactions reached $683,133,352$

9. In 2017 there were $90,003,848$ cards in circulation, and the number of transactions reaches $943,319,933$

10. In 2018 there were $167,205,578$ cards in circulation, and the number of transactions reached 2,922,698,905

11. In May 2019, there were $198,790,786$ cards in circulation, and the number of transactions reaches $422.602,216$.

The Bank Indonesia data shows an increasing number of using e-money in Indonesia. The use of e-money from 2009 has continued to increase until 2019. The continued growth of e-money in Indonesia, not only because of the many e-money publisher institutions but also modern shopping complements that open 24 hours. Thus, to facilitate payment transactions in modern shopping centers, people can use e-money comfortably and efficiently (Bank Indonesia (BI), 2019b).

This increase has the potential to shift the role of cash in conventional payment transactions. It because the use of e-money provides more advantages compared to cash, especially small-value operations such as e-money users no longer need to issue exact money or receive returns from merchants. Also, the use of e-money considered efficient because it can minimize the error calculation within transactions.

Figure 1. E-Money Growth in Indonesia (2009-2019)

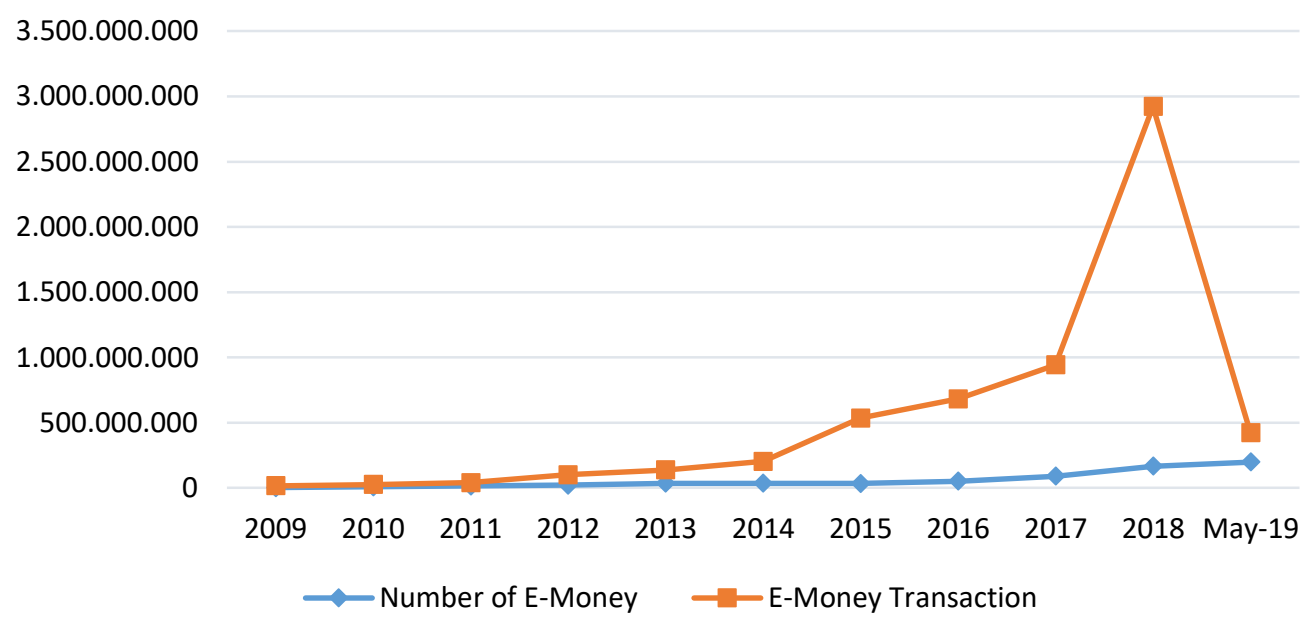




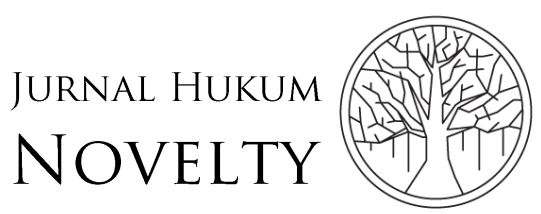

Volume 10, Issue 02, 2019, pp. 130-139

P-ISSN: $1412-6834$

E-ISSN: 2550-0090

\section{The Legality of Brizzi as Legal Payment In Indonesia}

E-money, as an alternative non-cash payment instrument, its use in financial transactions, in addition to providing benefits and convenience for the community, also has a variety of potential security risks (Junadi \& Sfenrianto, 2015). These potential risks, such as forgery or card duplication, data modification or e-money applications, theft, and other risks (Candrawati, 2014). Given the risks that faced for using e-money, minimizing risks needs to be regulated regarding the implementation of e-money in the realization of a transparent legal framework that can provide guarantees of protection to the public. In response to this problem, Bank Indonesia, as the party mandated to regulate the payment and monetary system, has issued PBI No.11/12/PBI/2009 concerning Electronic Money. However, at present, Bank Indonesia has issued a new regulation governing e-money, namely PBI No.20/6/PBI/2018 about Electronic Money promulgated in Jakarta on May 4, 2018.

Strengthening the rules for implementing e-money due to the use of e-money in Indonesia has experienced significant development. One of them is Brizzi, as an emoney product issued by Bank Rakyat Indonesia, one of the non-cash instruments that have increased the number of users and the number of transactions. Brizzi's fast and massive characteristics make it a payment instrument that will replace cash in some fields, such as transportation payment and shopping transactions.

Bank Rakyat Indonesia recorded a significant growth of Brizzi until the end of July 2018. Recorded until the end of July 2018, Brizzi transactions reached Rp. 1.9 Trillion compared to the transaction period of July 2017, which amounted to 216.5 Billion. It influenced by the use of Brizzi in some payment systems, such as the Commuter Line, Toll Road, and several merchants that have collaborated with BRI. Brizzi transactions increased was strengthened by the expansion and deepening of the e-money market by BRI in many regions in Indonesia. Promotion and marketing of Brizzi be strengthening among young people or millennials as an alternative payment.

From the results of an interview with Mr. Diah Fahri Sahada, as Customer Service at BRI KCP Merlung, said that Brizzi is a card-shaped e-money product issued by BRI to service digital process transactions. As an e-money product, Brizzi can be used as a substitute for cash to serve daily payment transactions, such as shopping transactions or other transactions carried out by providers of goods and services. Brizzi equipped with RFID (Radio Frequency Identification) technology that allows card users to make payment transactions by attaching the card to the reader machine.

The main features of Brizzi as e-money are 1) Maximum balance/limit is $\mathrm{Rp}$. $1,000,000,2)$ The minimum number of top-ups is Rp. 20,000, 3) Maximum Top-Up per month is Rp. 20,000,000, and 4). The validity period of Brizzi is unlimited. In 
addition to the main features of Brizzi, Mr. Diah Fahri Sahada also mentioned that the advantages of Brizzi as a digital payment instrument compared to using banknotes or coins are 1) Transactions are more comfortable because user only need to attach the Brizzi card to the reader machine and will be immediately processed after, 2) Transactions are faster because the payment process only takes a few seconds, 3) Transactions are safe and secure because they do not use cash, 4) Everyone can have Brizzi cards without having a BRI account, 5) Everyone can use Brizzi cards because they can be transferred and used by anyone to make payments or digital transactions, and 6) No administration costs.

Mr. Diah Fahri Sahada also added that Brizzi is categorized as e-money that can be used freely by the public because its implementation is under legal provisions in Indonesia. Brizzi is a non-cash payment instrument that has fulfilled the elements of e-money that stipulated in Article 1 Number 3, PBI. No.20/6/2018 concerning Electronic Money: 1) Published by Bank Rakyat Indonesia based on the value of money deposited in advance, 2) The amount of money on Brizzi is stored electronically on a media server or chip, and 3) The amount of money at Brizzi managed by Bank Rakyat Indonesia is not a deposit fund.

At present, the regulation of e-money in Indonesia regulated in PBI No. 20/6/PBI/2018 concerning Electronic Money. This Electronic Money PBI revokes 1) PBI No. 11/12/PBI/2009 concerning Electronic Money, 2) PBI No. 16/8/PBI/2014 concerning Amendments to Bank Indonesia Regulation Number 11/12/PBI/2009 concerning Electronic Money, and 3) PBI No. 18/17/PBI/2016 concerning the Second Amendment to Bank Indonesia Regulation Number 11/12/PBI/2009 concerning Electronic Money. PBI No. 20/6/PBI/2018 is generally issued with the following considerations: 1) The implementation of e-money is growing and varied along with the development of technological innovation and increasing community needs in the use of e-money, 2) The disparity in the performance of licensed operators and the increasing diversity of parties applying for e-money licenses are need to be addressed by strengthening institutional aspects to screen credible emoney providers, 3) E-money providers need to based on good financial conditions to be able to provide optimal benefits for the economy by always prioritizing consumer protection, and 4) The interrelationship between the implementation of e-money activities and the implementation of other business activities that are getting tighter and more complex are demanding the strengthening of integrated supervision of e-money providers.

In Indonesia, based on the scope of its implementation, e-money can be divided into two namely closed loop and open loop. This provision has been regulated in Article 3 paragraph (1) PBI No. 20/6/PBI/2018, which states that e-money is divide into closed loop, namely Electronic Money which can only be used as an instrument of payment to Providers of Goods and/or Services is the Electronic Money Issuer. The other is open loop, which is Electronic Money that can be used as a payment 
instrument for Providers of Goods and/or Services that are not Electronic Money Issuers. While based on the recording of user identity data, e-money can be divided into 2, namely unregistered and registered. This provision is regulated in Article 3 paragraph (2) PBI No. 20/6/PBI/2018.

Mrs. Diah Fahri Sahada said that Brizzi is a payment instrument for goods and/or service providers that have collaborated with BRI. Through Brizzi, users can access types of payments and transactions through every Brizzi logo places such as toll payments, parking payments, payment of public transportation such as trains and Transjakarta, shopping in retail stores such as Indomart and Alfamart and payment of entertainment or restaurants. Meanwhile, to get it, people do not need to record their identity data when creating a savings account. From the results of the interview, Brizzi categorized as e-money which scope of implementation is open loop and without recording user identity data, by Article 3 paragraph (1) and (2) PBI No. 20/6/PBI /2018.

\section{Conclusion}

The existence of using e-money to make payments in Indonesia is due to technological advances. Additionally, its existence makes the economic relationship much easier for the public. Bank Indonesia continues to encourage the use and operation of non-cash transactions using e-money, as well as the government has programmed the cashless movement for society. For that reasons, Bank Rakyat Indonesia has issued Brizzi as electronic money that can be used as an alternative to non-cash payments by users.

This e-money application despite its legality under varies of regulation in Indonesia, there are for sure attached-problems in an electronic era. That is why, the integration between regulation on e-money, providers of e-money, and users of emoney is needed and must be evaluated more and more. Thus, the economic loss will be avoided and the advantages will stand upon in every single society.

\section{References}

Anam, C. (2019). E-Money (uang elektronik) dalam perspektif Hukum Syari'ah. Qawãnïn: Journal of Economic Syaria Law, 2(1), 95-112. https://doi.org/10.30762/q.v2i1.1049

Bank Indonesia (BI). (2019a). Informasi perizinan penyelenggara dan pendukung jasa sistem pembayaran. Retrieved from https://www.bi.go.id/id/sistempembayaran/informasi-perizinan/uang-elektronik/penyelenggaraberizin/Pages/default.aspx

Bank Indonesia (BI). (2019b). Statistik Sistem Pembayaran. Retrieved July 13, 2019, from https://www.bi.go.id/id/statistik/sistempembayaran/uang-elektronik/contents/jumlah uang elektronik.aspx

Candrawati, N. N. A. (2014). Perlindungan hukum terhadap pemegang kartu emoney sebagai alat pembayaran dalam transaksi komersial. Jurnal Magister Hukum Udayana, 3(1), 1-16. https://doi.org/10.24843/JMHU.2014.v03.i01.p03

Disemadi, H. S., \& Roisah, K. (2019). Kontrak build operate transfer sebagai sarana 
mewujudkan kesejahteraan rakyat. Jurnal Komunikasi Hukum, 5(2), 126-138. http://dx.doi.org/10.23887/jkh.v5i2.18419

Firdaus, M. R. (2018). E-Money dalam perspektif hukum ekonomi syariah. Tahkim: Jurnal Hukum Dan Syariah, 14(1), 145-156. http://dx.doi.org/10.33477/thk.v14i1.613

Ghozali, M., \& Pambudi, T. (2018). Pengaruh permintaan e-money terhadap pendapatan per kapita di Indonesia. Al-Amwal : Jurnal Ekonomi dan Perbankan Syari'ah, 10(2), 185-198. https://doi.org/10.24235/amwal.v10i2.3358

Hanim, L. (2011). Pengaruh perkembangan teknologi informasi terhadap keabsahan perjanjian dalam perdagangan secara elektronik (e-commerce) di era globalisasi. Jurnal Dinamika Hukum, 11(Edsus), 59-67. https://doi.org/10.20884/1.jdh.2011.11.edsus.262

Junadi, \& Sfenrianto. (2015). A model of factors influencing consumer's intention to use e-payment system in Indonesia. Procedia Computer Science, 59(Iccsci), 214-220. https://doi.org/10.1016/j.procs.2015.07.557

Kamnar, N. P. (2014). The uses of electronic money and its impact on monetary policy. Journal of Contemporary Economic and Business Issues, 1(2), 79-92. Retrieved from eccfjournal.mk/index.php/journal-archive/volume-1/

Lee, B., \& Longe-Akindemowo, O. (1999). Regulatory issues in electronic money: A legal-economics analysis. Netnomics, 1(1), 53-70. https://doi.org/10.1023/A:1011445620486

Panurach, P. (1996). Money in electronic commerce: Digital cash, electronic fund transfer, and ecash. Communication of ACM, 39(6), 45-50. Retrieved from https://www.scss.tcd.ie/ htewari/bib_files/pan96.pdf

Pranoto, \& Salsabila, S. S. (2018). Eksistensi kartu kredit dengan adanya electronic money (e-money) sebagai alat pembayaran yang sah. Privat Law, 6(1), 24-33. Retrieved from https://jurnal.uns.ac.id/privatlaw/article/view/19222/15222

Safitri, D., \& Nainggolan, B. M. (2018). Implementation of campaign strategy for national non cash movement from Bank of Indonesia. Advances in Social Science, Education and Humanities Research, 150(ICoTic 2017), 13-17. Retrieved from https://www.atlantis-press.com/proceedings/icotic$17 / 25902361$

Samsumar, L. D. (2016). Konsep dan tantangan penggunaan teknologi e-money sebagai alat pembayaran alternatif di Indonesia. METHODIKA: Jurnal Teknik Informatika dan Sistem Informasi, 2(1), 102-107. Retrieved from http://www.methodika.net/index.php/jurnalmethodika/article/view/18

Sudarsono, M. (2013). Perlindungan konsumen pemegang uang elektronik (emoney) dihubungkan dengan Undang-Undang Nomor 8 Tahun 1999 Tentang Perlindungan Konsumen. Jurnal Wawasan Yuridika, 29(2), 896-907. Retrieved from http://www.ejournal.sthb.ac.id/index.php/jwy/article/view/71

Tazkiyyaturrohmah, R. (2018). Eksistensi uang elektronik sebagai alat transaksi keuangan modern. Muslim Heritage, 3(1), 21-39. Retrieved from http://jurnal.iainponorogo.ac.id/index.php/muslimheritage/article/view/124 $0 / 878$

Usman, R. (2017). Karakteristik uang elektronik dalam sistem pembayaran. Yuridika, 32(1), 134-166. https://doi.org/10.20473/ydk.v32i1.4431

Widyastuti, K., Handayani, P. W., \& Wilarso, I. (2017). Tantangan dan hambatan implementasi uang elektronik di Indonesia: Studi kasus Pt xyz. Jurnal Sistem Informasi, 13(1), 38-48. https://doi.org/10.21609/jsi.v13i1.465 